\title{
MENGHADAPI TUGAS KULIAH PERSPEKTIF ADVERSITY QUOTIENT
}

\author{
Muh. Haris Zubaidillah \\ Email: hariszub@gmail.com
}

Dalam memandang tugas-tugas kuliah, mahasiswa terbagi menjadi 3 golongan.

Golongan pertama, menganggap tugas-tugas tersebut seperti hantu yang menakutkan, serem, membuat stress, sehingga mata kuliah yang disukai adalah mata kuliah yang tidak memberikan tugas apapun, dan benci dengan mata kuliah yang selalu memberikan tugas-tugas, walaupun tugas itu sebenarnya cuma sedikit, maunya kuliah itu tidak mikir, tidak susah, tidak ada tugas, nilai tinggi, langsung dapat ijazah sarjana. sehingga kalau mendapat tugas, langsung histeris, shock, stress, bahkan merasa seperti orang paling susah sedunia. Sehingga timbul sikap sinis, sirik,menyalahkan orang lain.

Golongan kedua adalah golongan santai, tidak takut dengan tugas, tapi kalau tidak ada tugas juga biasa-biasa saja. 
jika dapat tugas dikerjakan dengan sesuai tuntutan aturan saja, tanpa ada inovasi.

Golongan ketiga mengaggap bahwa tugas-tugas kuliah merupakan makanan pokok yang wajib ada, mereka sangat menyukai dengan tugas-tugas, bahkan kecewa apabila ada mata kuliah yang tidak memberikan tugas apa2, rasa ingin tahu yang tinggi, semangat yang tinggi, cinta terhadap tantangan, bahkan memandang tugas-tugas dan tantangan bukan sebagai hantu yang menakutkan, namun sebagai langkah dan peluang dalam mengembangkan pengetahuan dan bakat untuk meraih keberhasilan dan kesuksesan.

Dalam kaitannya dengan ADVERSITY QUOTIENT, golongan pertama disebut quitter, golongan kedua disebut camper, dan golongan ketiga disebut claimber.

\section{APA ITU ADVERSITY QUOTIENT}

Apakah adversity quotient (AQ) itu? Menurut Stoltz, AQ adalah kecerdasan untuk mengatasi kesulitan. "AQ merupakan faktor yang dapat menentukan bagaimana, jadi atau tidaknya, serta sejauh mana sikap, kemampuan dan kinerja Anda terwujud di dunia," tulis Stoltz. Pendek kata, orang yang memiliki AQ tinggi akan lebih mampu mewujudkan citacitanya dibandingkan orang yang AQ-nya lebih rendah. 
Ketika akhirnya Thomas Alva Edison (1847 - 1931) berhasil menemukan baterai yang ringan dan tahan lama, dia telah melewati 50.000 percobaan dan bekerja selama 20 tahun. Tak heran kalau ada yang bertanya, "Mr. Edison, Anda telah gagal 50.000 kali, lalu apa yang membuat Anda yakin bahwa akhirnya Anda akan berhasil?" Secara spontan Edison langsung menjawab, "Berhasil? Bukan hanya berhasil, saya telah mendapatkan banyak hasil.

Untuk memberikan gambaran, Stoltz meminjam terminologi para pendaki gunung. Dalam hal ini, Stoltz membagi para pendaki gunung menjadi tiga bagian: 1. Quitter (yang menyerah). Para quitter adalah para pekerja yang sekadar untuk bertahan hidup). Mereka ini gampang putus asa dan menyerah di tengah jalan.

Tipe quitter memiliki cirri-ciri:

Memilih untuk keluar, menghindari kewajiban, mundur dan berhenti

Menghentikan pendakian

Menolak kesempatan yang telah diberikan

Meninggalkan dorongan inti untuk merdeka

Murung, sinis, mudah menyalahkan orang lain, sirik 
2. Camper (berkemah di tengah perjalanan) Para camper lebih baik, karena biasanya mereka berani melakukan pekerjaan yang berisiko, tetapi tetap mengambil risiko yang terukur dan aman. "Ngapain capek-capek" atau "segini juga udah cukup" adalah moto para campers. Orang-orang ini sekurangkurangnya sudah merasakan tantangan, dan selangkah lebih maju dari para quitters. Sayangnya banyak potensi diri yang tidak teraktualisasikan, dan yang jelas pendakian itu sebenarnya belum selesai.

Tipe ini memiliki ciri-ciri:

Sudah melakukan sedikit lalu berhenti ditengah jalan Melepaskan kesempatan untuk maju Mudah puas dengan apa yang telah dicapai 3. climber (pendaki yang mencapai puncak). Para climber, yakni mereka, yang dengan segala keberaniannya menghadapi risiko, akan menuntaskan pekerjaannya. Mereka mampu menikmati proses menuju keberhasilan, walau mereka tahu bahwa akan banyak rintangan dan kesulitan yang menghadang.

Namun, di balik kesulitan itu ia akan mendapatkan banyak kemudahan."Karena sesungguhnya sesudah kesulitan itu ada kemudahan”. Dalam konteks ini, para climber dianggap memiliki AQ tinggi. Dengan kata lain, AQ membedakan antara 
para climber, camper, dan quitter. tipe orang yang memiliki ciri-ciri:

Orang yang memiliki pikiran terus tentang peluang Tidak memikirkan suatu hal sebagai hambatan Tidak menyesali kebelumberhasilan Pembelajar seumur hidup

Jawaban luar biasa dari pencipta lampu pijar itu menjadi salah satu contoh ekstrem seorang climber (pendaki)yang dianggap memiliki kecerdasan mengatasi kesulitan (adversity quotient, AQ) tinggi. Terminologi AQ memang tidak sepopuler kecerdasan emosi (emotional quotient) milik Daniel Goleman, kecerdasan finansial (financial quotient) milik Robert T. Kiyosaki, atau kecerdasan eksekusi (execution quotient) karya Stephen R. Covey. AQ ternyata bukan sekadar anugerah yang bersifat given. AQ ternyata bisa dipelajari. Dengan latihan-latihan tertentu, setiap orang bisa diberi pelatihan untuk meningkatkan level AQ-nya. Manusia sejati adalah manusia yang jika menempuh perjalanan yang sulit, mereka selalu optimis; sedangkan jika mereka melewati perjalanan yang mudah mereka malah khawatir.

Dalam kehidupan nyata, hanya para climbers-lah yang akan mendapatkan kesuksesan dan kebahagiaan sejati. Sebuah penelitian yang dilakukan Charles Handy-seorang pengamat 
ekonomi kenamaan asal Inggris terhadap ratusan orang sukses di Inggris memperlihatkan bahwa mereka memiliki tiga karakter yang sama. Yaitu, pertama, mereka berdedikasi tinggi terhadap apa yang tengah dijalankannya. Dedikasi itu bisa berupa komitmen, kecintaan atau ambisi untuk melaksanakan pekerjaan dengan baik. Kedua, mereka memiliki determinasi. Kemauan untuk mencapai tujuan, bekerja keras, berkeyakinan, pantang menyerah dan kemauan untuk mencapai tujuan yang diinginkannya. Dan ketiga, selalu berbeda dengan orang lain. Orang sukses memakai jalan, cara atau sistem bekerja yang berbeda dengan orang lain pada umumnya. Dua dari tiga karakter orang sukses yang diungkapkan Handy dalam The New Alchemist tersebut erat kaitannya dengan kemampuan seseorang dalam menghadapi tantangan

AQ mempunyai tiga bentuk (Stoltz, 2000:9) yaitu (1) AQ sebagai suatu kerangka kerja konseptual yang baru untuk memahami dan meningkatkan semua jenis kesuksesan, (2) merupakan suatu ukuran untuk mengetahui respon terhadap kesulitan, dan (3) merupakan serangkaian peralatan dasar yang memiliki dasar ilmiah untuk memperbaiki respon terhadap kesulitan.(Zubaidillah, 2017) 


\section{DAFTAR PUSTAKA}

Zubaidillah, M.H. (2017). NILAI-NILAI PENDIDIKAN ADVERSITY QUOTIENT PADA CERITA NABI MÛSÂ DALAM ALQURAN. AI Qalam: Jurnal IImiah Keagamaan Dan Kemasyarakatan 11. 